\title{
Bacterial expression and purification of biologically active human TFF2
}

\author{
ZHUANG Yong-Hui ${ }^{1,2, \#}$, LI Si-Man ${ }^{1,3, \text {, }}$, YU Guo-Yu ${ }^{1,3}$, ZHANG Yong ${ }^{1}$, \\ XIANG Yang ${ }^{1}$, ZOU Hao ${ }^{4,}$, LEE Wen-Hui ${ }^{1, *}$ \\ (1. Key Laboratory of Animal Models and Human Disease Mechanisms of Chinese Academy of Sciences \& Yunnan Province, Kunming Institute of Zoology, \\ Kunming Yunnan 650223, China; 2. Department of Neurosurgery, Yunnan No.2 People's Hospital, Kunming Yunnan 650021, China; 3. Department of \\ Biochemistry, Kunming Medical College, Kunming Yunnan 650500, China; 4. Department of Hepatobiliary Surgery, the Second \\ Affiliated Hospital of Kunming Medical College, Kunming Yunnan 650101, China)
}

\begin{abstract}
Human trefoil factor 2 (hTFF2) is considered as one of the most important initiators of mucosal healing in the gastrointestinal tract by promoting cell migration and suppressing apoptosis. However, it is hard to obtain hTFF2 from human tissue and many recombinant hTFF2 produced in vitro exist as fusion proteins. The purpose of the present study was to produce native hTFF2 while maintaining its biological activities. The open reading frame of hTFF2 was inserted into a pET-32a(+) expression vector, and hTFF2-TRX fusion protein was successfully expressed in Escherichia coli and purified by Nickel-nitrilotriacetic acid affinity chromatography and reverse-phase HPLC steps. The recombinant fusion protein (purity $>95 \%$ ) was cleaved by Factor Xa at $23{ }^{\circ} \mathrm{C}$ to release hTFF2. After removal of Factor Xa and undigested fusion proteins, hTFF2 was purified and identified by SDS-PAGE and Western blotting. The yield of recombinant hTFF2 was about $5 \mathrm{mg} / \mathrm{L}$. The recombinant hTFF2 could promote IEC-6 cells migration and in vitro wound healing via the activation of ERK1/2. Recombinant hTFF2 could also inhibit apoptosis of HCT-116 cells induced by $50 \mu \mathrm{mol} / \mathrm{L}$ ceramide. In summary, our results showed that the recombinant hTFF2 was expressed in E. coli and successfully purified after cleavage with the fusion partner with high yield while maintaining its biological activities. Recombinant hTFF2 might be useful for investigating the molecular mechanism of hTFF2 and development of hTFF2-related drugs.
\end{abstract}

Key words: TFF2; Expression; Cell migration; Anti-apoptosis; Wound healing

Abbreviations: TFF, trefoil factor; SP, spasmolytic polypeptide; TRX, thioredoxin; NSAIDs, non-steroidal antiinflammatory drugs; ERK, extracellular signal-regulated kinase; pERK1/2, phospho-ERK1/2; PARP, poly ADP-ribose polymerase; EGF, epidermal growth factor; TGF- $\alpha$, transforming growth factor- $\alpha$; PCR, polymerase chain reaction; IPTG, isopropyl-1-thio- $\beta$-D-galactopyranoside; FCS, fetal calf serum; BSA, bovine serum albumin; PMSF, phenylmethylsulfonyl fluoride; SDS-PAGE, SDS-polyacrylamide gel electrophoresis; Ni-NTA, Nickel-nitrilotriacetic acid

\section{人 TFF2 基因的原核表达与纯化}

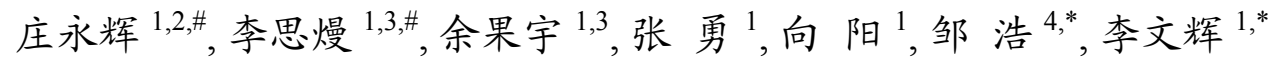 \\ (1. 中国科学院和云南省动物模型与人类疾病机理重点实验室, 云南昆明 $650223 ; 2$. 云南省第二人民医院 神经外科, 云南 昆明 650021 ; \\ 3. 昆明医学院生物化学教研室, 云南昆明 $650500 ; 4$. 昆明医学院第二附属医院 肝胆外科, 云南昆明 650101)
}

Received date: 2011-12-14; Accepted date: 2012-02-22

Foundation items: This work was supported by grants from the National Basic Research Program of China (973 Program, 2010CB529800), the Chinese National Natural Science Foundation (81160302, 30870304), the "Western Light Project" from the Chinese Academy of Sciences (Y102291081), and the Science and Technology Department of Yunnan Province (2011C1139)

*Corresponding author (通信作者), E-mail: newzouhao@163.com

Conflict of interest: The authors declare that there are no conflicts of interest

收稿日期: 2011-12-14; 接受日期：2012-02-22

基金项目：“973”项目(2010CB529800); 国家基金委面上项目(81160302,30870304); 中国科学院“西部之光”(Y102291081)

第一作者简介: 庄永辉(1964-), 男, 副主任医师, 研究方向: 神经肿瘤的分子生物学; 李思熳(1981-), 女, 讲师。研究方向: 肿瘤的生物化学与分 子生物学

\#共同第一作者(Authors contributed equally to the work) 
摘要: 人三叶因子 2(hTFF2) 具有促进细胞迁移和抑制细胞调亡的活性, 所以被认为是胃肠黏膜修复的启动 者之一。因为从人组织中获得 hTFF2 比较困难, 而且体外产生的重组 hTFF2 大都以融合蛋白的形式存在, 所以该 研究的目的是在体外产生不带任何融合蛋白的游离型 hTFF2。hTFF2 的开放阅读框被插入 pET-32a $(+)$ 表达载体, 然后在大肠杆菌中表达出带有硫氧还蛋白融合部分的 hTFF2 融合蛋白。进而利用融合蛋白的组氨酸标签使用镍 亲和色谱柱以及反向高压色谱柱对目的蛋白进行纯化。23 ${ }^{\circ} \mathrm{C}, \mathrm{FXa}$ 因子裂解纯度高达 $95 \%$ 的融合蛋白以得到游离 型 hTFF2。在去除 FXa 因子和尚未被切开的融合蛋白后, 获得的游离型 hTFF2 被 SDS-PAGE 和 Western blotting 所证实。重组游离型 hTFF2 的产量约为 $5 \mathrm{mg} / \mathrm{L}$, 并且 hTFF2 能促进 IEC-6 细胞的迁移以及体外的伤口修复, 而这 些活性是依赖于 ERK1/2 的激活。同时, hTFF2 也能抑制 $50 \mu \mathrm{mol} / \mathrm{L}$ 神经鞘氨醇所引起的 HCT-116 细胞的调亡。 总之, 研究结果表明, 在大肠杆菌中高产量地成功表达出具有生物学活性的游离型 hTFF2, 这为研究 TFF2 的分子 机制, 以及研制和开发 TFF2 的相关药物都提供很大的帮助。

关键词: TFF2; 表达; 细胞迁移; 抗调亡; 伤口修复

中图分类号: Q786; Q251 文献标志码：A 文章编号：0254-5853-(2012)02-0144-07

Trefoil factors (TFFs) are a family of peptides that share three-looped TFF-domains, each of which is composed of 38 or 39 amino acid residues in which six cysteine residues are linked in the configuration of 1-5, 24, and 3-6, thus forming a characteristic three-leaved structure (Thim, 1989). Human TFFs, including hTFF1 (pS2), hTFF2 (spasmolytic peptide, SP), and hTFF3 (intestinal trefoil factor, ITF), are synthesized and secreted mainly by mucin-secreting epithelial cells in the gastrointestinal tract (Suemori et al, 1991). Both hTFF1 and hTFF3 only have a single TFF-domain, whereas hTFF2 has two TFF-domains (Sands \& Podolsky, 1996). The TFF peptides are believed to contribute to mucosal healing and restitution by promoting cell migration and suppressing apoptosis (Dignass et al, 1994; Taupin et al, 2000).

The hTFF2 is mainly expressed in the mucous neck cells of the gastric mucosa where it boosts epithelial restitution and prevents infection (Sands \& Podolsky, 1996; Taupin et al, 2000). Recent reports showed that the alteration of hTFF2 expression was closely associated with carcinogenesis and progression of gastric cancer by affecting cell proliferation, migration, infiltration, and apoptosis (Cook et al, 1999; Dignass et al, 1994; Fox et al, 2007; Hanby et al, 1993; Oertel et al, 2001). In TFF2deficient mice, gastric epithelial cell proliferation decreased, and acid secretion and susceptibility to nonsteroidal anti-inflammatory drugs (NSAIDs) increased (Farrell et al, 2002). However, the injury induced by NSAIDs in stomachs could be prevented or cured after TFF2 administration (Poulsen et al, 1999). Although diverse roles of hTFF2 have been investigated, the detailed molecular mechanism of hTFF2-mediated signaling transduction is largely unknown, partly because there is an insufficient amount of hTFF2. Thus, the expression of hTFF2 in vitro would be beneficial for the mechanism study of hTFF2.

In the present work, we used RT-PCR techniques to amplify hTFF2 cDNA and inserted it into an N-terminal histidine tag containing bacterial expression vector. After the N-terminal histidine tag was cleaved by Factor Xa, the tagless recombinant hTFF2 was purified with high yield. The recombinant hTFF2 was able to induce rat intestinal epithelial cell IEC-6 migration, promote in vitro wound healing, and inhibit human colorectal cancer cell HCT-116 apoptosis.

\section{Materials and Methods}

\subsection{Construction of hTFF2 expression plasmid}

Total RNA was extracted from surgical resection specimens of human gastric mucosa using a TRIzol Reagent kit (Tiangen Biotech, China) according to the manufacturer's instructions. The cDNA of hTFF2 was amplified by a reverse transcriptional reagent kit (TaKaRa, China). The open reading frame (ORF) of hTFF2 was inserted into a pMD-19T simple vector (TaKaRa, China) by conventional methods. Briefly, a polymerase chain reaction (PCR) was conducted with the cDNA of hTFF2 as the template. The sense primer used was: $5^{\prime}$-ggtaccatcgagggaagggagaaaccctcccctgc-3' , which containing a Kpn I site (italicized), the coding sequence for a Factor Xa recognition site (boldface), and $\mathrm{N}$-terminal residues of hTFF2 (underline). The antisense primer used was: 5' -gaattcttagtaatggcagtcttc-3' , which containing an EcoR I site (italicized), the stop codon (boldface), and C-terminal residues of hTFF2 (underline). The PCR was performed with an initial denaturation at $94{ }^{\circ} \mathrm{C}$ for 4 min, followed by 35 cycles of $94{ }^{\circ} \mathrm{C}$ for $30 \mathrm{~s}, 65^{\circ} \mathrm{C}$ for $30 \mathrm{~s}$, and $72{ }^{\circ} \mathrm{C}$ for $45 \mathrm{~s}$, and a final extension at $72{ }^{\circ} \mathrm{C}$ for $7 \mathrm{~min}$. The PCR products 
were first subcloned into the pMD-19T simple vector. After digestion with Kpn I and EcoR I on the pMD-19ThTFF2 plasmid, the recovered hTFF2 ORF was ligated into the pET-32a(+) vector (Novage, Germany) at Kpn I and EcoR $I$ sites to construct the expression plasmid, designated as pET-32a(+)-hTFF2. Clones with a correct sized insert were verified by DNA sequencing.

\subsection{Expression, purification, and identification of recombinant hTFF2}

The E. coli expression strain BL21 (DE3) (Novage, Germany) was transformed with pET-32a(+)-hTFF2 plasmid. Transformed cells were grown at $37^{\circ} \mathrm{C}$ up to an absorbance of about $0.6-0.8$ at $600 \mathrm{~nm}$ and then induced with $0.5 \mathrm{mmol} / \mathrm{L}$ isopropyl-1-thio- $\beta$-D-galactopyranoside (IPTG) and cultivated for an additional period of $3.5 \mathrm{~h}$ at $37{ }^{\circ} \mathrm{C}$. The cells were centrifuged at $8000 \mathrm{r} / \mathrm{min}$ for 10 min and resuspended in $100 \mathrm{~mL}$ equilibration buffer $(50$ $\mathrm{mmol} / \mathrm{L}$ sodium phosphate, $\mathrm{pH} 8.0$, with $0.3 \mathrm{~mol} / \mathrm{L} \mathrm{NaCl}$ and $10 \mathrm{mmol} / \mathrm{L}$ imidazole). The cells were then lysed by sonication (Ultrasonic Cell Crusher JY92-2D) at $350 \mathrm{~W}$ for 80 cycles ( $6 \mathrm{~s}$ working, $10 \mathrm{~s}$ free) in an ice-water bath. The supernatant recovered by centrifugation at 16000 $\mathrm{r} / \mathrm{min}$ for $30 \mathrm{~min}$ was applied to a Ni-Sepharose column packed with $3 \mathrm{~mL}$ nickel-nitrilotriacetic acid (Ni-NTA) resin (Sigma, American). Elution of the fusion protein was carried out with elution buffer $(50 \mathrm{mmol} / \mathrm{L}$ sodium phosphate, $\mathrm{pH} 8.0$, with $0.3 \mathrm{~mol} / \mathrm{L} \mathrm{NaCl}$ and $250 \mathrm{mmol} / \mathrm{L}$ imidazole). The fractions containing thioredoxin (TRX)hTFF2 were pooled and applied on a reverse-phase HPLC (RP-HPLC) Zorbax $300 \mathrm{SB} \mathrm{C}_{4}$ column (Elite, China) equilibrated with $0.1 \%(\mathrm{v} / \mathrm{v})$ trifluoroacetic $\mathrm{acid} / \mathrm{water}$. The elution was performed at a flow rate of $0.7 \mathrm{~mL} / \mathrm{min}$. At the acetonitrile concentration of $60 \%$, a peptide peak was collected and verified to TRX-hTFF2 by Western blotting. The TRX-hTFF 2 concentration was determined by a protein assay kit (Bio-Rad, USA), then $50 \mu \mathrm{g}$ TRX-hTFF2 fusion protein was incubated with 1 $\mu \mathrm{g}$ Factor Xa (Biolabs, New England) for $16 \mathrm{~h}$ at $23{ }^{\circ} \mathrm{C}$ in cleavage buffer $(20 \mathrm{mmol} / \mathrm{L}$ Tris- $\mathrm{HCl}, 100 \mathrm{mmol} / \mathrm{L}$ $\mathrm{NaCl}$, and $2 \mathrm{mmol} / \mathrm{L} \mathrm{CaCl}_{2}, \mathrm{pH}$ 8.0). After digestion, the products were analyzed by SDS-polyacrylamide gel electrophoresis (SDS-PAGE), and hTFF2 was further purified by Factor Xa removal resin column (Qiagen, USA) and a Ni-NTA column to remove the TRX-tag and undigested fusion protein according to the manufacturer's instructions. The flow-through fractions were collected and dialyzed against $10 \mathrm{mmol} / \mathrm{L}$ sodium phosphate $(\mathrm{pH} 7.5)$ and lyophilized. The recombinant
hTFF2 was analyzed by SDS-PAGE and Western blotting with anti-hTFF2 antibody (Santa Cruz, USA).

\subsection{Cell culture}

Rat intestinal epithelial cell line IEC-6 and human colorectal cancer cell line HCT-116 were obtained from the American Type Culture Collection (Manassas, USA). The IEC-6 cells were cultured in Dulbecco's Modified Eagle Medium (DMEM) containing 5\% fetal calf serum (FCS), $100 \mathrm{U} / \mathrm{mL}$ penicillin, and $100 \mathrm{mg} / \mathrm{mL}$ streptomycin. The HCT-116 cells were cultured in DMEM containing $10 \% \mathrm{FCS}, 100 \mathrm{U} / \mathrm{mL}$ penicillin, and $100 \mathrm{mg} / \mathrm{mL}$ streptomycin. The cells were grown in a humidified atmosphere with $5 \% \mathrm{CO}_{2}$ at $37{ }^{\circ} \mathrm{C}$.

\subsection{Cell migration assay}

Cell migration activity was tested with a modified Boyden chamber assay as described previously (Liu et al, 2008). The bottom sides of the Millicells ( $8 \mu \mathrm{m}$ pore, Millipore, USA) were coated with collagen type 1 (10 $\mu \mathrm{g} / \mathrm{mL}$ ) from rat tail (Sigma). After starvation overnight, the IEC- 6 cells were detached, then $1 \times 10^{5}$ cells were planted into the top of each chamber. The recombinant hTFF2 was added into the bottom of the chambers. After $16 \mathrm{~h}$, the non-migratory cells on the upper membrane surface were removed with a cotton swab, and the migrated cells were dyed with freshly prepared $0.025 \%$ crystal violet in $0.1 \mathrm{~mol} / \mathrm{L}$ borate buffer $(\mathrm{pH} 9.0)$ containing $2 \%$ ethanol for $30 \mathrm{~min}$ at room temperature. The bound crystal violet was eluted with $1 \mathrm{~mL} \mathrm{10 \%}$ acetic acid and the migration activity was expressed as the value monitored at $586 \mathrm{~nm}$ of extraction.

\section{5 in vitro wound healing assay}

Wound healing assay was performed as reported previously (Hoying \& Williams, 1996), with minor modification. The IEC-6 cells cultured to confluent in 6well plates were starved overnight, and the cell monolayer was scratched by a standard $200-\mu \mathrm{L}$ pipette tip across the diameter of the wells. The medium and non-adherent cells were removed, and the plates were rinsed twice with PBS. The fresh medium containing recombinant hTFF2 was added into the plates and changed every $24 \mathrm{~h}$. Time-lapse photography of the wounding edges was performed under an inverted-phase microscope within $72 \mathrm{~h}$.

\subsection{The phosphorylation level of ERK1/2}

Confluent monolayers of IEC-6 cells were treated with recombinant hTFF 2 for $0 \mathrm{~min}, 15 \mathrm{~min}, 30 \mathrm{~min}$, and $60 \mathrm{~min}$. The collected cells were then washed and immediately lysed on ice with the lysis buffer (50 
mmol/L HEPES, $\mathrm{pH} 7.4$, containing $5 \mathrm{mmol} / \mathrm{L}$ EDTA, $50 \mathrm{mmol} / \mathrm{L} \mathrm{NaCl}, 1 \%$ Triton X-100, $50 \mathrm{mmol} / \mathrm{L} \mathrm{NaF}, 5$ $\mathrm{mg} / \mathrm{mL}$ aprotinin, $5 \mathrm{mg} / \mathrm{mL}$ leupeptin, $1 \mathrm{mmol} / \mathrm{L} \mathrm{Na}_{3} \mathrm{VO}_{4}$, and $1 \mathrm{mmol} / \mathrm{L} \mathrm{PMSF})$. After centrifugation, the lysate $(20 \mu \mathrm{g})$ was loaded on a SDS-PAGE gel and transferred onto a PVDF membrane. The membrane was subsequently blocked with $3 \%$ BSA and incubated with anti-ERK2 and anti-pERK1/2 primary antibodies and secondary antibodies (Santa Cruz, USA). Protein bands were visualized with super signal reagents (Pierce, USA) as described previously (Taupin \& Podolsky, 1999).

\subsection{Anti-apoptosis activity assay}

Anti-apoptosis effect was assessed by measuring the cleavage of caspase substrate p116-[poly ADP-ribose polymerase (PARP)] as described in previous research (Kinoshita et al, 2000). Confluent monolayers of HCT116 cells in 6-well plates were starved and then treated with recombinant hTFF2 for $24 \mathrm{~h}$. Ceramide $(50 \mu \mathrm{mol} / \mathrm{L})$ was added to the treated HCT-116 cells, and the cells were incubated for a further $24 \mathrm{~h}$. Apoptosis activity was assessed by measuring the cleavage of caspase substrate p116-PARP as analyzed by Western blotting with antiPARP antibody (Santa Cruz, USA) (Kinoshita et al, 2000).

\subsection{Statistical analysis}

The data were expressed as mean $\pm S D$. Comparisons were performed by Student's $t$-test. $P<0.05$ was considered statistically significant.

\section{Results}

\subsection{Construction of the pET-32a(+)-hTFF2 expression plasmid}

To construct an effective expression system for hTFF2, the plasmid pET-32a(+) was selected as the expression vector. As shown in Fig. 1A, the protein sequence of cloned hTFF2 was identical to that of

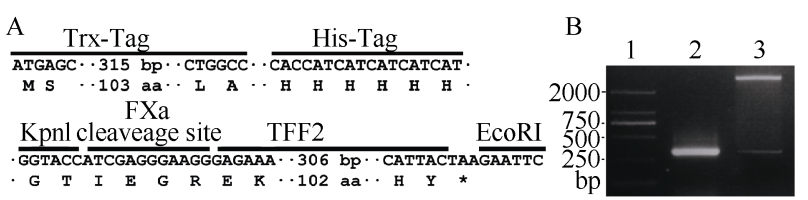

Fig. 1 Construction of the pET-32a(+)-hTFF2 expression plasmid

(A) The profile of nucleotide acid and amino acid sequences of the pET32a $(+)$-hTFF2 plasmid. The plasmid includes the sequences of TRX-tag, His-tag, Factor Xa cleavage site and hTFF2. (B) Identification of hTFF2 by restriction endonucleases digestion. The recombinant pET-32a(+)-hTFF2 expression plasmid was digested by Kpn I and EcoR I, and a 310 bp DNA fragment was released. Lane 1, standard molecular marker; lane 2, PCR product of hTFF2; lane 3, digestion production of the pET-32a(+)-hTFF2 plasmid.
GenBank (Accession No.7032), and Kpn I (at Nterminus) and EcoR I (at C-terminus) sites were introduced to construct pET-32a(+)-hTFF2 plasmid. The Factor Xa sequence provided a cleavage site (Fig. 1A) to obtain the recombinant hTFF2 without additional amino acid at its N-terminus. The hTFF2 ORF (310 bp) was ligated into $\mathrm{pET}-32 \mathrm{a}(+)$ vector between the Kpn I and EcoR I sites. The recombinant plasmid was confirmed by releasing a 310 bp DNA fragment after restriction enzyme digestion (Fig. 1B), and by DNA sequencing (data not shown).

\subsection{Expression and purification of recombinant hTFF2}

The pET-32a(+)-hTFF2 expression plasmid was transformed into BL21 (DE3) cells. As shown in Fig. 2A, after induction by IPTG for $3.5 \mathrm{~h}$, the cells were collected and lysed by sonication, and the TRX-hTFF2 fusion protein mainly existed in the ultrasonic supernatant. His-tag in fusion protein provided an effective purification step by His-select Ni-NTA column.

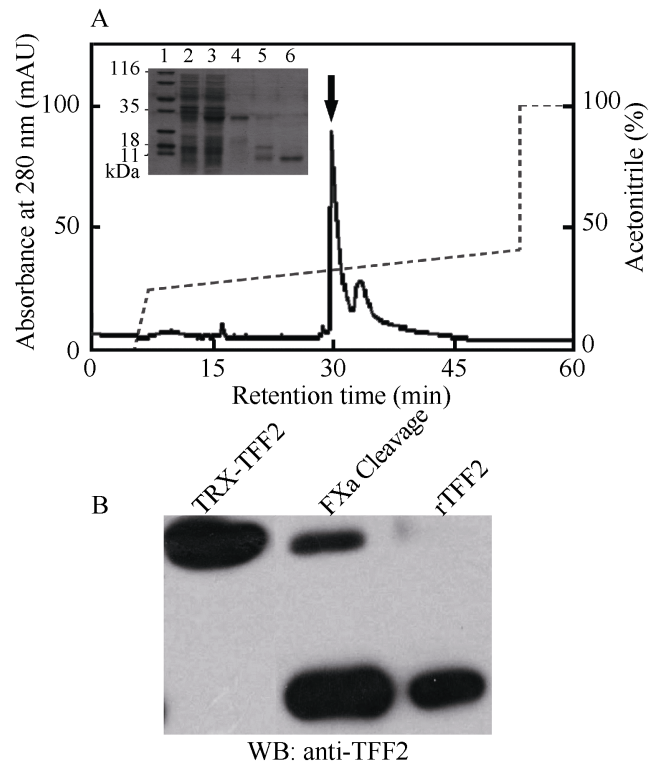

Fig. 2 Expression, purification, and identification of recombinant hTFF2

(A) Purification of the recombinant TRX-hTFF2 in a reverse-phase HPLC $\mathrm{C}_{4}$ column. The column was equilibrated with $0.1 \%(\mathrm{v} / \mathrm{v})$ trifluoroacetic $\mathrm{acid} /$ water. The elution was performed at a flow rate of $0.7 \mathrm{~mL} / \mathrm{min}$. The highest peak was the TRX-hTFF2 fusion protein, as indicated by an arrow. Inset: SDS-PAGE analysis of the process of expression, purification and cleavage of TRX-hTFF2. Lane 1, the molecular weight marker; lane 2, cell lysate without IPTG induction; lane 3 , cell lysate with $0.5 \mathrm{mmol} / \mathrm{L}$ IPTG induction; lane 4, the elution fraction of HPLC after a Ni-NTA column; lane 5, cleavage of TRX-hTFF2 by Factor Xa; lane 6, the flow-through fraction from a Ni- NTA column of cleaved TRX-hTFF2. (B) Western blotting with anti-hTFF2 antibody analysis of TRX-hTFF2 fusion protein, cleavage of TRX-hTFF2 by Factor Xa, and purified recombinant hTFF2. 
The fusion protein was finally eluted with elution buffer containing $250 \mathrm{mmol} / \mathrm{L}$ imidazole. The elution was then subjected to RP-HPLC, and the highest peak was the recombinant TRX-hTFF2 protein (Fig. 2A). The TRXhTFF2 fusion protein was then cleaved with Factor Xa and further purified by Factor Xa removal column and the Ni-NTA resin. The flow-through fractions were the recombinant hTFF2 without any extension amino acids at its N-terminus, and SDS-PAGE showed a single band with the theoretical molecular weight of $1.3 \times 10^{4}$. In addition, the single band was verified to human hTFF2 by Western blotting analysis with the special anti-hTFF2 antibody (Fig. 2B).

\section{3 hTFF2 promoted cell migration and in vitro wound healing}

One of the most important roles of TFFs is to promote cell migration and wound healing (Taupin \& Podolsky, 2003). The recombinant hTFF2 showed strong activity in promoting cell migration and wound healing in vitro. After treatment with hTFF 2 for $16 \mathrm{~h}$, the motility of IEC-6 cells was increased in a dose-dependent manner and the activity was about 2-fold greater in $200 \mathrm{nmol} / \mathrm{L}$ hTFF2 compared with the negative control (BSA) (Fig. $3 \mathrm{~A})$. In the in vitro wound healing assay, the IEC-6 cell monolayer was "wounded" by $200-\mu 1$ standard tips. Obvious increases in the rate of wound closure were found at each time point in the presence of $200 \mathrm{nmol} / \mathrm{L}$ hTFF2, and the wound achieved almost $95 \%$ closure at 72 h (Fig. 3B).

\subsection{Activation of ERK1/2 in IEC-6 cells stimulated by hTFF2}

Phosphorylation of ERK1/2 is important for signal transduction of TFFs, especially for cell migration (Taupin \& Podolsky, 2003). The phosphorylation levels of ERK1/2 in IEC-6 cells stimulated with recombinant hTFF2 were analyzed. As shown in Fig. 3C, $200 \mathrm{nmol} / \mathrm{L}$ hTFF2 significantly enhanced the phosphorylation level of ERK1/2.

\subsection{The anti-apoptotic activity of hTFF2}

Suppressing apoptosis is an important procedure at the early stages of wound healing (Bossenmeyer-Pourié et al, 2002). In the present study, apoptosis of HCT-116 cells was assessed by analyzing the cleavage of p116PARP. Results showed that $50 \mu \mathrm{mol} / \mathrm{L}$ ceramide induced obvious apoptosis as observed by the disappearance of the $1.16 \times 10^{5}$ band of PARP in HCT-116 cells. However, after pre-incubation with hTFF2 protein for $24 \mathrm{~h}$, the HCT-116 cells were further treated with

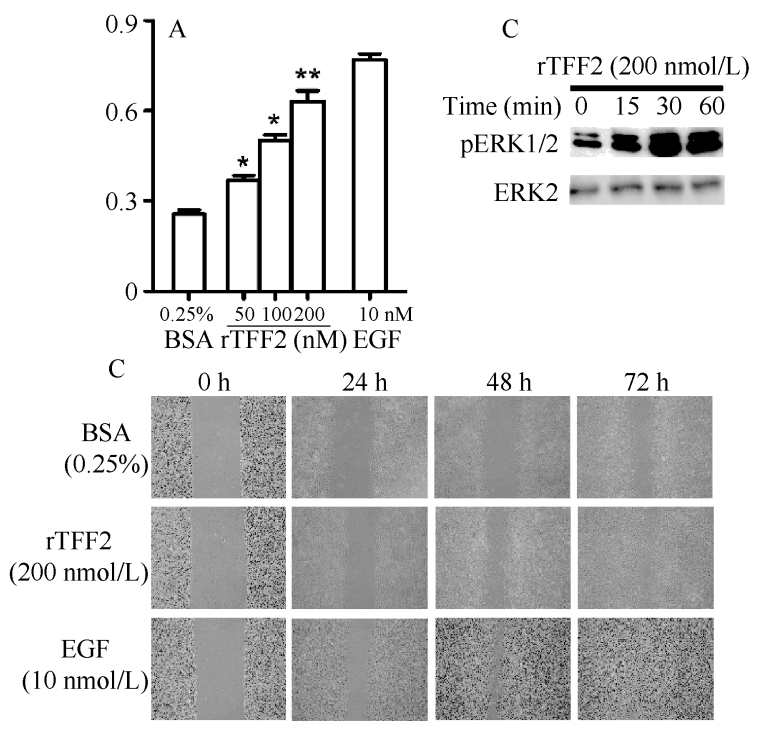

Fig. 3 Recombinant hTFF2 promotes migration and wound healing of IEC- 6 cells

(A) Cell migration activity stimulated by $50-200 \mathrm{nM}$ hTFF 2 was tested by a Boyden chamber assay as described in the text. BSA was used as a control. Values represent means $\pm S D$ of three independent experiments. *: $P<0.05$; **: $P<0.01$. (B) Closure of an artificial wound in IEC-6 cell monolayer stimulated by hTFF2. BSA $(0.25 \%)$ and EGF $(10 \mathrm{nmol} / \mathrm{L})$ were used as controls. The representative data of three independent experiments are shown. Scale bars equal to $100 \mu \mathrm{m}$. (C) hTFF2 activated ERK1/2 in IEC-6 cells. The cells starved in a serum-free medium overnight were stimulated with $200 \mathrm{nmol} / \mathrm{L}$ hTFF2 for times indicated. The pERK1/2 levels of the cells were examined by Western blotting. Data were the representative of at least three independent experiments.

C2-ceramide for another $24 \mathrm{~h}$. The cleavage of $1.16 \times 10^{5}$ band was inhibited, suggesting that hTFF2 suppressed the apoptosis of HCT-116 cells induced by ceramide (Fig. 4).

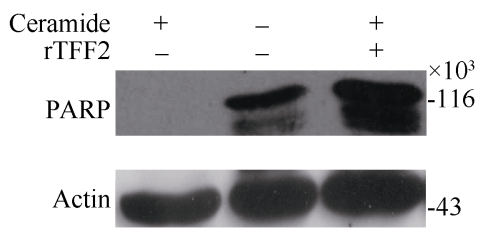

Fig. 4 Recombinant hTFF2 inhibits HCT-116 cells apoptosis

Confluent HCT-116 cells were pre-incubated with hTFF2 for $16 \mathrm{~h}$. Apoptosis of HCT-116 cells was induced by further incubation with $50 \mu \mathrm{mol} / \mathrm{L}$ ceramide for $24 \mathrm{~h}$. The apoptosis was evaluated by Western blotting with anti-PARP antibody. The recombinant hTFF2 inhibited the cleavage of $1.16 \times 10^{5}$ band, suggesting that hTFF2 could suppress HCT-116 apoptosis induced by ceramide.

\section{Discussion}

Trefoil factors are small secretory stable peptides. 
Due to the compact TFF-domain formed by three intrachain disulfide bonds among six conserved cysteine residues, TFFs are resistant to protease (Kinoshita et al, 2000). Additionally, TFFs play important roles in mucosal repair, cytoprotection, and tumor suppression in the gastrointestinal tract (Perry et al, 2008; Wong et al, 1999). The roles of TFFs in vivo and in vitro indicate that TFFs may have potential value in drug development for curing gastrointestinal tract mucosa injury. In a rat model, porcine TFF2 accelerated the healing of gastric ulceration (Poulsen et al, 1999), recombinant human hTFF2 and TFF3 also protected against both ethanol and indomethacin induced gastric injury markedly (Babyatsky et al, 1996). Because hTFF2 has very important biological functions but very limited amounts can be prepared from human tissue extracts, much effort has been made to express hTFF2 peptide in yeast at relative low quantity (Thim et al, 1993) or in Escherichia coli with an additional tag linked to hTFF2 (Sun et al, 2010). Improved quality and quantity of hTFF2 is urgently needed to help explore its functions.

In this study, the pET-32a(+) system with TRX-tag was used to express hTFF2. Using the TRX-tag as the fusion partner significantly enhanced the solubility of human hTFF2 and facilitated the formation of disulfide bonds, which is important for hTFF2 to maintain its conformation and exert biological activities. Moreover, His-tag could be used to purify fusion protein by NiNTA resin (LaVallie et al, 1993; Stewart et al, 1998). As shown in Fig. 2A, most recombinant TRX-hTFF2 produced in E. coli was soluble. After purification by Ni-NTA resin and RP-HPLC, the purity of the fusion protein was above 95\%. To exclude the influence of TRX, the TRX-tag was removed from the fusion protein by Factor Xa, Factor Xa removal resin column, and $\mathrm{Ni}$ NTA column. The recombinant native hTFF2 without additional amino acids was finally produced. The yield of recombinant hTFF2 was approximately $5 \mathrm{mg} / \mathrm{L}$. The SDS-PAGE showed a single band with the theoretical molecular weight of about $1.3 \times 10^{4}$ (Fig. $2 \mathrm{~A}$ ), and the $1.3 \times 10^{4}$ band was verified to human hTFF2 by Western blotting with anti-hTFF2 antibody (Fig. 2B).

Together with epidermal growth factor (EGF) and

\section{References:}

A lison MR, Chinery R, Poulsom R, Ashwood P, Longcroft JM, Wright NA. 1995. Experimental ulceration leads to sequential expression of spasmolytic polypeptide, intestinal trefoil factor, epidermal growth factor and transforming growth factor alpha mRNAs in rat transforming growth factor alpha (TGF- $\alpha$ ), TFFS participated in the re-epithelization of wounded tissue by promoting mucosal repair and wound healing (Wong et al, 1999). As an acute-phase protein, hTFF2 was speculated to facilitate mucosal healing by promoting cell migration in the early phase (Alison et al, 1995). In this study, 50-200 nmol/L hTFF2 significantly promoted IEC-6 cell migration in a dose-dependent manner. Similar results were also obtained in the wound healing model. The $200 \mathrm{nmol} / \mathrm{L}$ hTFF2 significantly increased wound closure, with the wound achieving almost 95\% closure at $72 \mathrm{~h}$ (Fig. 3B). The results showed that recombinant hTFF2 had similar activities of cell migration and wound healing as Bm-TFF2, a twodomain TFF from frog species Bombina maxima expressed by the pET-32a(+) system (Yu et al, 2010). It is well known that cell migration-promoting activity is dependent on the activation of ERK1/2 (Chwieralski et al, 2004; Klemke et al, 1997; Storesund et al, 2008). In our study, $200 \mathrm{nmol} / \mathrm{L}$ recombinant hTFF2 significantly enhanced the phosphorylation level of ERK1/2, suggesting that the promotion of cell migration activity of hTFF2 was ERK1/2-dependent. Additionally, hTFF2 can act as a morphogen in the presence of TFF1 and promote cell survival via inhibition of cell apoptosis (Lalani et al, 1999). Consistent with hTFF2 inhibited apoptosis of colon cancer cell lines and breast cancer cell lines (Siu et al, 2004), native hTFF2 can also inhibit HCT-116 cell apoptosis induced by C2-ceramid. In contrast with the results, the recombinant TFF3 protein increased cartilage-degrading and promote chondrocyte apoptosis, which was a previously unrecognized proapoptotic function of TFFs (Rösler et al, 2010). In addition, the recombinant hTFF2 in the present research also resisted trypsin degradation (data not shown).

In summary, native human hTFF2 was successfully expressed by a pET-32a(+) expression system. The recombinant hTFF2 without additional amino acid tags promoted cell migration and wound healing and inhibited cell apoptosis. The expression of hTFF2 in E. coli may be useful for studying molecular mechanisms of TFF2mediated signaling and the development of TFF2-related drugs.

stomach[J]. J Pathol, 175(4): 405-414.

Babyatsky MW, deBeaumont M, Thim L, Podolsky DK. 1996. Oral trefoil peptides protect against ethanol- and indomethacin-induced gastric injury in rats[J]. Gastroenterology, 110(2): 489-497. 
Bossenmeyer-Pourié C, Kannan R, Ribieras S, Wendling C, Stoll I, Thim L, Tomasetto C, Rio MC. 2002. The trefoil factor 1 participates in gastrointestinal cell differentiation by delaying G1S phase transition and reducing apoptosis[J]. J Cell Biol, 157(5): 761-770.

Chwieralski CE, Schnurra I, Thim L, Hoffmann W. 2004. Epidermal growth factor and trefoil factor family 2 synergistically trigger chemotaxis on BEAS-2B cells via different signaling cascades[J]. Am J Respir Cell Mol Biol, 31(5): 528-537.

Cook GA, Familari M, Thim L, Giraud AS. 1999. The trefoil peptides TFF2 and TFF3 are expressed in rat lymphoid tissues and participate in the immune response[J]. FEBS Lett, 456(1): 155-159.

Dignass A, Lynch-Devaney K, Kindon H, Thim L, Podolsky DK. 1994. Trefoil peptides promote epithelial migration through a transforming growth factor beta-independent pathway[J]. J Clin Invest, 94(1): 376-383.

Farrell JJ, Taupin D, Koh TJ, Chen D, Zhao CM, Podolsky DK, Wang TC. 2002. TFF2/SP-deficient mice show decreased gastric proliferation, increased acid secretion, and increased susceptibility to NSAID injury[J]. J Clin Invest, 109(2): 193-204.

Fox JG, Rogers AB, Whary MT, Ge ZM, Ohtani M, Jones EK, Wang TC. 2007. Accelerated progression of gastritis to dysplasia in the pyloric antrum of TFF2 ${ }^{-/}$C57BL6 $\times$Sv129 Helicobacter pyloriinfected mice[J]. Am J Pathol, 171(5): 1520-1528.

Hanby AM, Poulsom R, Singh S, Elia G, Jeffery RE, Wright NA. 1993. Spasmolytic polypeptide is a major antral peptide: distribution of the trefoil peptides human spasmolytic polypeptide and $\mathrm{pS} 2$ in the stomach[J]. Gastroenterology, 105(4): 1110-1116.

Hoying JB, Williams SK. 1996. Effects of basic fibroblast growth factor on human microvessel endothelial cell migration on collagen I correlates inversely with adhesion and is cell density dependent[J]. J Cell Physiol, 168(2): 294-304.

Kinoshita K, Taupin DR, Itoh H, Podolsky DK. 2000. Distinct pathways of cell migration and antiapoptotic response to epithelial injury: structure-function analysis of human intestinal trefoil factor[J]. Mol Cell Biol, 20(13): 4680-4690

Klemke RL, Cai S, Giannini AL, Gallagher PJ, de Lanerolle P, Cheresh DA. 1997. Regulation of cell motility by mitogen-activated protein kinase[J]. J Cell Biol, 137(2): 481-492.

Lalani EN, Williams R, Jayaram Y, Gilbert C, Chaudhary KS, Siu LS, Koumarianou A, Playford R, Stamp GW. 1999. Trefoil factor-2, human spasmolytic polypeptide, promotes branching morphogenesis in MCF-7 cells[J]. Lab Invest, 79(5): 537-546.

LaVallie ER, DiBlasio EA, Kovacic S, Grant KL, Schendel PF, McCoy JM. 1993. A thioredoxin gene fusion expression system that circumvents inclusion body formation in the E. coli cytoplasm[J]. Nat Biotechnol, 11(2): 187-193.

Liu SB, He YY, Zhang Y, Lee WH, Qian JQ, Lai R, Jin Y. 2008. A novel non-lens $\beta \gamma$-crystallin and trefoil factor complex from amphibian skin and its functional implications[J]. PLoS One, 3(3): e1770.

Oertel M, Graness A, Thim L, Buhling F, Kalbacher H, Hoffmann W. 2001. Trefoil factor family-peptides promote migration of human bronchial epithelial cells: synergistic effect with epidermal growth factor[J]. Am J Respir Cell Mol Biol, 25(4): 418-424.

Perry JK, Kannan N, Grandison PM, Mitchell MD, Lobie PE. 2008.
Are trefoil factors oncogenic?[J]. Trends Endocrinol Metab, 19(2): 74-81

Poulsen SS, Thulesen J, Christensen L, Nexø E, Thim L. 1999. Metabolism of oral trefoil factor 2 (TFF2) and the effect of oral and parenteral TFF2 on gastric and duodenal ulcer healing in the $\operatorname{rat}[\mathrm{J}]$. Gut, 45(4): 516-522.

Rösler S, Haase T, Claassen H, Schulze U, Schicht M, Riemann D, Brandt J, Wohlrab D, Müller-Hilke B, Goldring MB, Sel S, Varoga D, Garreis F, Paulsen FP. 2010. Trefoil factor 3 is induced during degenerative and inflammatory joint disease, activates matrix metalloproteinases, and enhances apoptosis of articular cartilage chondrocytes[J]. Arthritis Rheum, 62(3): 815-825.

Sands BE, Podolsky DK. 1996. The trefoil peptide family[J]. Annu Rev Physiol, 58(1): 253-273.

Siu LS, Romanska H, Abel PD, Baus-Loncar M, Kayademir T, Stamp GWH, Lalani el N. 2004. TFF2 (trefoil family factor2) inhibits apoptosis in breast and colorectal cancer cell lines[J]. Peptides, 25(5): 855-863.

Stewart EJ, Åslund F, Beckwith J. 1998. Disulfide bond formation in the Escherichia coli cytoplasm: an in vivo role reversal for the thioredoxins[J]. EMBO J, 17(19): 5543-5550.

Storesund T, Hayashi K, Kolltveit KM, Bryne M, Schenck K. 2008. Salivary trefoil factor 3 enhances migration of oral keratinocytes[J]. Eur J Oral Sci, 116(2): 135-140.

Suemori S, Lynch-Devaney K, Podolsky DK. 1991. Identification and characterization of rat intestinal trefoil factor: tissue- and cellspecific member of the trefoil protein family[J]. Proc Natl Acad Sci USA, 88(24): 11017-11021.

Sun Y, Wu W, Wang L, Liang GP, Zhang Y, Lv SJ, Wang Z, Wang SL, Peng X. 2010. Overexpression of hTFF2 in the pET system and its in vitro pharmacological characterization[J]. Biomed Pharmacother, 64(5): 343-347.

Taupin D, Podolsky DK. 1999. Mitogen-activated protein kinase activation regulates intestinal epithelial differentiation[J]. Gastroenterology, 116(5): 1072-1080.

Taupin D, Podolsky DK. 2003. Trefoil factors: initiators of mucosal healing[J]. Nat Rev Mol Cell Biol, 4(9): 721-732.

Taupin DR, Kinoshita K, Podolsky DK. 2000. Intestinal trefoil factor confers colonic epithelial resistance to apoptosis[J]. Proc Natl Acad Sci USA, 97(2): 799-804.

Thim L. 1989. A new family of growth factor-like peptides. 'Trefoil' disulphide loop structures as a common feature in breast cancer associated peptide (pS2), pancreatic spasmolytic polypeptide (PSP), and frog skin peptides (spasmolysins)[J]. FEBS Lett, 250(1): $85-90$

Thim L, Norris K, Norris F, Nielsen PF, Bjørn SE, Christensen M, Petersen J. 1993. Purification and characterization of the trefoil peptide human spasmolytic polypeptide (hSP) produced in yeast[J]. FEBS Lett, 318(3): 345-352.

Wong WM, Poulsom R, Wright NA. 1999. Trefoil peptides[J]. Gut, 44(6): 890-895.

Yu GY, Zhang Y, Xiang Y, Jiang P, Chen ZM, Lee W, Zhang Y. 2010. Cell migration-promoting and apoptosis-inhibiting activities of Bm-TFF2 require distinct structure basis[J]. Biochem Biophys Res Commun, 400(4): 724-728. 